\title{
A Comparison between China's Share-Based Payment Accounting Standard and IFRS2
}

\author{
Hongman Zhang \\ Changchun University of Science \& Technology, Changchun 130022, China \\ E-mail: Zhanghm1995@163.com \\ Xianfeng Liu \\ Troop 65043, Chinese People's Liberation of China \\ Tel: 86-431-6981 469 E-mail: 1xfz@vipsina.com
}

\begin{abstract}
The international convergence of accounting standards requires more for the constitution and the perfect of China's accounting standards. China's share-based payment standard appears later. The background for the appearance of international accounting standards' share-based payment standard, and the difference between China's new standards about share-based payment and the international accounting standards deserve more studies and researches.
\end{abstract}

Keywords: Share-based payment standard, International convergence, International financial report standard (IFRS)

In China, along with the development of market economy and the maturity of security market, more and more enterprises adopt the share-based payment and the option payment. The payment ways are diversified. The share-based payment means that enterprises give equity tools to employees or other parties in order to get their services. Here the so-called equity tools include shares, options, and others.

The share-based payment appears in high-tech enterprises in $50 \mathrm{~s}$ at $20^{\text {th }}$ century in America. The emergence of Enron Event and the financial cheating of World Com and World-Link Communications make the share-based payment attract the attentions from academic fields and industrial fields and also the doubt of investors. Therefore, the background for the appearance of international accounting standards' share-based payment standard, and the difference between China's new standards about share-based payment and the international accounting standards deserve more studies and researches.

\section{The issue of International Financial Report Standard No.2 ----- the share-based payment}

The stock incentive mechanism firstly appears in America, where there is the manager share and equity incentive mechanism. Before, there is not similar try.

The No.25 option of American Accounting Principles Board (APB) in 1972 established the values of stocks and options as expenses. However, due to the absence of concepts and the irrationality of calculation, it was criticized and questioned widely. In 1995, the US Financial Accounting Standards Board issued the SFAS123, which permits enterprises to calculate the expenses for stocks and options and disclose necessary information in accounting statements. After the Enron Event in 2004, the US Financial Accounting Standards Board amends the SFAS123 and regulates the share-based payment strictly.

After 2000, many countries start to make up the share-based payment standards. In April, 2000, the Institute of State Authorized Public Accountants in Denmark issued the discussion draft of "the accounting treatment of share- based payment". In 2001, Germany Accounting Standards Committee drafted the "accounting treatment of stock-option plan and similar salary arrangement". In Dec. 2002, Accounting Standards Board of Japan issued the summarized report on share-based payment.

Meanwhile, the International Accounting Standards Board (IASB) is busy with the issue of share-based payment standard. In Sep. 2001, IASB issued the discussion draft. In the process, it gains wide support and help from many social fields, including the academic field, the industrial field, and the investment field. In Nov. 2002, IASB issued the No.2 discussion draft for the share-based payment. In Apr. 2004, it issued the International Financial Report Standard No.2 ------ the Share-Based Payment formally, which is put into effect in Jan. 2005.

In Feb. 2005, European Commission approves the application of the International Financial Report Standard No. 2 ------ the Share-Based Payment in Europe. And the valid date is traced back to Jan. $1^{\text {st }}, 2005$. 
Then, the International Financial Report Standard No.2 ------ the Share-Based Payment has gained wide attentions and acceptance in the world. It adopts the fair calculation mode and makes mature accounting treatment on "share-based payment", mainly regulating the share-based payment activities, which include not only the payment for employees but also the exchange of commodities.

China's Enterprise Accounting Standards No.11 ------ Share-based Payment is a new item in the enterprise accounting standards amended in 2006 by the Finance Ministry. The establishment of this standard and relevant calculation principle makes the share-based rewards regular and legal. It displays the association of China's accounting standards and International Accounting Standards.

\section{The constitution and perfection process for China's share-based payment standard}

In Nov. 2002, the Finance Ministry of China issued the "Directive suggestions for state-owned high- tech enterprises developing stock incentive pilot" (No.[2002]508), which regulates the stock incentive activities in state-owned high-tech enterprises.

In Aug. 2005, five departments, including China Securities Regulatory Commission, the Finance Ministry of China, and the State-owned Assets Supervision and Administration Commission of State Council issued the "Directive Suggestions for Listed Companies' Stock Reform". For the listed company completed the stock separate reform, the management level can apply the stock incentive mechanism. The document notices that the specific methods, assessment measurements, and equipped system are constituted by the security regulatory sectors and relevant agencies.

In Oct. 2005, the State Council sends the "Notice on Improving the Quality of Listed Company" to the Securities Regulatory Commission, which points that listed companies should explore and regulate the stock incentive mechanism, and activate the motives of management level and employees.

In Nov. 2005, China Securities Regulatory Commission takes in advices from the society openly, concerning the "listed company's stock incentive regulation", with the hope of regulating the application of stock incentive in listed company.

In Jan. 2006, Securities Regulatory Commission issued the "Listed Company Stock Incentive Management Ways (for trial). Then, $\mathrm{G}$ listed companies start the stock incentive plans.

In Feb. 2006, the Finance Ministry issued the "Enterprise Accounting Standard No.11 ------ Share- based Payment". It regulates the share-based payment for the first time in China, uniting different treatments in practice. It is a new detailed standard for the practice of share-based payment. Before, few regulations concern this field and no regulation deals with the calculation and the confirmation. This standard will complement the absence. The calculation rules established by this standard are in accordance with the international standard. It also considers China's practice in share-based payment.

\section{Main differences between China's share-based payment and International Financial Report Standards}

Enterprise Accounting Standards No.11 ------ Share-based Payment takes references from International Financial Report Standards No.2 ------ Share-based Payment (IFRS2) and considers China's practical conditions. It regulates the share-based payment. And the two standards have similar principles. In detail, the differences are displayed as follow.

(1) Different name

In China, it is "share payment standard". In the world, it is "share-based payment".

(2) Different scope

IFRS2 regulates all payment transactions that are based on shares in the process of subjects getting or taking commodities or services, including share-based salaries to employees and share-based payment to other parties.

In China, the share payment standard mainly regulates the share payment that is used by enterprises to obtain employees or others' services, which includes equity payment and cash payment. In addition, the share payment for getting commodities has been regulated by other rules.

(3) Different calculation

IFRS2 regulates that all share-based payment is confirmed in financial reports and the calculation is based on fair values. In the transaction focusing on getting commodities or accepting services, the calculation should follow the fair value of commodities or services. Only when it can not be calculated precisely, can it be calculated by equity tools. The transactions between enterprises and employees or other service providers should be calculated by the fair value of equity tools. It is a typical case in which the fair value can not be valued precisely. 
In China, the standard regulates that: if the share payment for employees is based on equities, the calculation should be based on the fair value of equity tools. If the share payment for other service providers is based on equities and the fair value can be valued precisely, the calculation should follow the fair value. If other service providers' fair value can not be valued precisely but the fair value of equity tools can valued precisely, the calculation should follow the fair value at the service date. If the share payment is in cash, the calculation should follow the fair value of enterprises' debts based on enterprises' shares and other equity tools.

(4) The establishment of fair value

IFRS2 regulates: as for the transaction between enterprises and employees, the fair value should be calculated at the date when the equity tool is given. As for the transaction between enterprises and service or commodity providers, the fair value should be calculated at the date when the commodity or service is received. As for the commodity and service calculated with the base of equity tools' fair value, relevant calculation does not consider the empowered conditions (except the market as empowered condition). Therefore, the final sum established with the base of commodities and services is determined by the qualified equity tools.

In China, the standard only mentions that the fair value of equity tools is determined by the standards of Financial Tools' Establishment and Calculation. It does not regulate how to calculate the fair value of cash liquidity.

(5) The disclosure

China's standards regulate that enterprises should disclose relevant share payment information and the financial conditions at that time, together with the influences on business in the appendix. IFRS2 requires more detailed disclosure compared that of China. IFRS2 regulates that the disclosure can help financial reports users understand the fair value of commodities or services, or the fair value of empowered equity tools. These points do not included in new standard.

Because China's securities market is still undeveloped, the popularization of fair value is difficult. IFRS2 has regulated the fair value precisely and in detail. To compare and analyze accounting standards can help us to acquire experiences and references. Build up a mechanism for rational accounting standards, and speed up the perfection of accounting standards.

In perspective of development, we should speed up the coordination of China's standard with International Accounting Standards. To compare and analyze accounting standards can testify the convergence of China's new standards and International Financial Report Standards. As China builds the accounting standards, we should take references from International Financial Report Standards. Although there are still some differences between international standards and China's new standard, theses differences are based on China's present conditions. The socialist system, market mechanism, accounting standards' execution environment, and legal environment determine that the new accounting standard must take China's conditions into consideration. Probe into the right connection between international standards and China's new standards and make the later be in convergence with the international standards and be in accordance with China's special conditions at the same time.

\section{References}

Chang, Xuemei. (2006). Probe into new enterprise accounting standards. Commercial Accounting. No.4.

$\mathrm{Hu}$, Xin. (2007). Analyze main changes of new basic standards and the differences with international accounting standards. Friends of Accounting. No.7.

Liu, Chi. (2007). Studies on differences between China accounting standards and international accounting standards. Money China. No.2.

Lu, Shuping. (2006). On the differences between China new accounting standards and international accounting standards. Northern Economy. No.6.

Wang, Jianxin. (2007). On the International Harmonization of China's Accounting Standards. Beijing: China Financial \& Economic Publishing House.

Wang, Xiangyao. (2007). A Comparison Between China New Accounting Standards and International Financial Reporting Standards. Shanghai: Lixin Accounting Publishing House.

Yu, Shulian. (2007). A comparison between the application of new accounting standards and international standards. Accountant. No.2. 